\section{Ploidy Variation and Genetic Diversity in Dichroa}

Timothy A. Rinehart ${ }^{1}$

USDA-ARS, Southern Horticultural Laboratory, 810 Highway 26 West, Poplarville, MS 39470

Brian E. Scheffler USDA-ARS, Genomics and Bioinformatics Research Unit, 141 Experiment Station Road, JWDSRC, Stoneville, MS 38776

\section{Sandra M. Reed}

USDA-ARS, Floral and Nursery Plants Research Unit, Tennessee State University Otis L. Floyd Nursery Research Center, 472 Cadillac Lane, McMinnville, TN 37110

Additional index words. simple sequence repeats, SSR, microsatellite markers, Hydrangea macrophylla, Dichroa febrifuga, Dichroa versicolor, Hydrangea indochinensis

Abstract. Recent evidence suggests a close genetic relationship between Hydrangea macrophylla (Thunb.) Ser. and D. febrifuga Lour., which supports previous morphological and DNA sequence data. This relationship was confirmed by the production of fertile intergeneric hybrids. We characterize the genetic diversity of available $D$. febrifuga plants, both cultivars and wild-collected taxa, as breeding material to improve $\boldsymbol{H}$. macrophylla. Relatively high genetic diversity is seen among $D$. febrifuga, which splits into two main clusters. We also document considerable differences in genome size when compared with previously characterized $D$. febrifuga. Dichroa versicolor (Fortune) D.R. Hunt plants were also included and data suggest that $D$. versicolor could be a hybrid between $H$. macrophylla and $D$. febrifuga, similar to the intergeneric hybrids produced by recent breeding efforts. Because native $\boldsymbol{H}$. macrophylla plants do not overlap extensively with $D$. febrifuga populations, we tested Hydrangea indochinensis Merr. as a possible parent because endemic $H$. indochinensis populations overlap regions where $D$. febrifuga and $D$. versicolor have been collected. However, results suggest that $H$. indochinensis does not share a genetic background with $D$. versicolor. Taxonomic revision of Dichroa is warranted, especially because we document several more intergeneric hybrids from selfsown, open-pollinated sources.

The genus Dichroa Lour., which is a member of the Hydrangeaceae, includes 12 species native to eastern Asia and adjacent islands (Shumei and Bartholomew, 2001). Dichroa febrifuga Lour. is one of the 50 fundamental herbs in Chinese herbology and a well-known medicinal plant (Duke and Ayensu, 1985). It is also the most ornamental member of the genus and is commercially available in the United States. Dichroa febrifuga is a small shrub, growing 1 to $2 \mathrm{~m}$ in height, and has evergreen or semievergreen foliage when grown in USDA cold hardiness zone 7 and warmer (Hinkley, 2005). In colder areas, landscape plants are generally deciduous and have

Received for publication 5 May 2009. Accepted for publication 7 July 2009.

We thank Glyn Church, David Creech, Mike Dirr, Bobby Green, Dan Hinkley, Sean Hogan, Ozzie Johnson, Josh Kardos, and Kristen VanHoose for graciously donating tissue and plants.

Mention of trade names or commercial products in this article is solely for the purpose of providing specific information and does not imply recommendation or endorsement by the U.S. Department of Agriculture.

${ }^{1}$ To whom reprint requests should be addressed; e-mail tim.rinehart@ars.usda.gov.

sepals have not been observed in Dichroa (Reed et al., 2008). Flowers are described as ranging in color from pink to blue (Hinkley, 2005). Unlike $H$. macrophylla, which requires aluminum to produce blue flowers, some selections of D. febrifuga produce blue flowers even in the absence of aluminum. The most notable trait is the small, glossy fruits consisting of iridescent or metallic blue berries that remain on the shrub for many months. Intergeneric hybridizations could combine desirable traits from $D$. febrifuga such as blue fruits, stable flower color, larger flowers, and evergreen foliage with cold-hardiness and the showy flowers with large sepals that are found in H. macrophylla.

Phylogenetic analyses of rbcL and matK sequences in the Hydrangeaceae suggest a close relationship between the genus Dichroa and H. macrophylla (Hufford et al., 2001; Soltis et al., 1995). Morphological investigations also support a close relationship between these two species (Hufford, 2001). Simple sequence repeat (SSR) markers indicate $H$. macrophylla is more genetically similar to $D$. febrifuga than to other Hydrangea species (Rinehart et al., 2006). SSR markers also indicate a relationship between $H$. indochinesis and D. febrifuga (Rinehart and Reed, 2008). Hydrangea indochinesis was considered by McClintock (1957) to be a synonym for $H$. macrophylla ssp. stylosa (H. f.) Thomson, but Hinkley (2003) has referred to it as $H$. scandens ssp. indochinesis Merr. SSR marker data indicate that $H$. indochinensis is more closely related to $D$. febrifuga than to H. macrophylla or H. scandens (L. f.) Ser. (Rinehart and Reed, 2008).

Hybridization studies support a close genetic relationship between $H$. macrophylla and $D$. febrifuga. Fertile reciprocal hybrids between $H$. macrophylla and D. febrifuga have been produced (Jones et al., 2006; Kardos, 2008; Kardos et al., 2006; Reed et al., 2008). At the time those crosses were initiated, only one selection of D. febrifuga was available for hybridizations. This selection, GUIZ48, is described as being a clone collected in Guizhou Province, China, by Peter Wharton at the University of British Columbia Botanical Garden (Hinkley, 2005). Chromosome counts indicated that this selection is a hexaploid with $2 n=$ $6 x=108$ chromosomes (Reed et al., 2008).

Since the original hybridizations between D. febrifuga and H. macrophylla were performed, several more Dichroa selections and cultivars have become available in the United States. In addition, plants thought to be naturally occurring hybrids between Dichroa and Hydrangea have been identified (Glyn Church, personal communication). The objectives of this study were to examine ploidy levels of Dichroa selections, evaluate the genetic diversity within the available Dichroa germplasm, determine if naturally occurring hybrids between Dichroa and $\mathrm{Hy}$ drangea exist, and identify possible parental species. Ploidy was determined using flow cytometry, whereas genetic diversity and hybridity were evaluated using SSR markers.

\section{Materials and Methods}

Plant materials. The 37 genotypes tested in this study are listed in Table 1. Plant tissue was obtained from plants in the collection at the Nursery Research Center in McMinnville, $\mathrm{TN}$, or from public or commercial sources. Samples included tissue from 25 D. febrifuga plants representing 19 genotypes; one of these was a plant labeled as $D$. hirsuta Gagnep. but was shown to be $D$. febrifuga. Two previously described (Reed et al., 2008) intergeneric hybrids (samples \#27 and 30) and four selfsown, open-pollinated hybrids (samples \#26, 31, 32, and 33) suspected to be hybrids between Dichroa and Hydrangea were included. 'Round Blue', 'White Lace', and 'Pink Candy' (samples \#31, 32, and 33) were found 
Table 1. Samples listed by species and cultivar where applicable along with source of material, identifying notes for select taxa, and estimated genome size.

\begin{tabular}{|c|c|c|c|}
\hline No. & Species & Source ${ }^{z}$ & DNA (pg), mean $\pm \mathrm{se}^{\mathrm{y}}$ \\
\hline 1 & Dichroa febrifuga & NRC & $6.9 \pm 0.09$ \\
\hline 2 & Dichroa febrifuga & $\mathrm{NRC}$ & $6.8 \pm 0.09$ \\
\hline 3 & Dichroa febrifuga & $\mathrm{NRC}$ & $6.9 \pm 0.15$ \\
\hline 4 & Dichroa febrifuga & WG & \\
\hline 5 & Dichroa febrifuga 'Yellow Wings' & $\mathrm{CN}$ & $6.5 \pm 0.17$ \\
\hline 6 & Dichroa febrifuga HWJCM011 & HW & \\
\hline 7 & Dichroa hirsuta & WG & \\
\hline 8 & Dichroa febrifuga (Chadwell collection) & $\mathrm{CN}$ & $6.0 \pm 0.11$ \\
\hline 9 & Dichroa febrifuga & WG & \\
\hline 10 & Dichroa febrifuga BSWJ6610 & $\mathrm{CN}$ & $12.9 \pm 0.09$ \\
\hline 11 & Dichroa febrifuga aff. hirsuta BSWJ8371 & $\mathrm{CN}$ & $6.7 \pm 0.08$ \\
\hline 12 & Dichroa febrifuga & WG & \\
\hline 13 & Dichroa febrifuga & WG & \\
\hline 14 & Dichroa febrifuga 'Yamaguchi Hardy' & UGA & $12.8 \pm 0.23$ \\
\hline 15 & Dichroa febrifuga (Woodleigh Gardens \#7) & WG & $12.6 \pm 0.20$ \\
\hline $16 \mathrm{a}$ & Dichroa febrifuga (Woodleigh Gardens \#11) & WG & $12.5 \pm 0.15$ \\
\hline $\mathrm{b}$ & Dichroa febrifuga (Woodleigh Gardens \#11) & GN & \\
\hline $17 \mathrm{a}$ & Dichroa febrifuga HWGUIZ48 & HW & \\
\hline $\mathrm{b}$ & Dichroa febrifuga & $\mathrm{CF}$ & \\
\hline $\mathrm{c}$ & Dichroa febrifuga & UGA & \\
\hline $\mathrm{d}$ & Dichroa febrifuga & UGA & \\
\hline $\mathrm{e}$ & Dichroa febrifuga GUIZ48 & $\mathrm{NRC}$ & $17.6 \pm 0.20$ \\
\hline $18 \mathrm{a}$ & Dichroa febrifuga 'Yamaguchi Select' & UGA & $17.4 \pm 0.15$ \\
\hline $\mathrm{b}$ & Dichroa febrifuga 'Yamaguchi Select' & MAST & \\
\hline 19 & Dichroa febrifuga (dwarf) & $\mathrm{CN}$ & $17.6 \pm 0.20$ \\
\hline 20 & Hydrangea indochinensis & $\mathrm{NRC}$ & $4.8 \pm 0.04$ \\
\hline 21 & Hydrangea indochinensis & ITS & $5.0 \pm 0.06$ \\
\hline 22 & Hydrangea indochinensis & ITS & $5.1 \pm 0.08$ \\
\hline 23 & Hydrangea indochinensis & WG & \\
\hline 24 & Hydrangea indochinensis & WG & \\
\hline 25 & Hydrangea indochinensis & WG & \\
\hline 26 & Hydrangea indochinensis hybrid & WG & \\
\hline 27 & Hydrangea macrophylla 'Veitchii' $\times$ Dichroa febrifuga & $\mathrm{NRC}$ & $10.9 \pm 0.07$ \\
\hline 28 & Dichroa versicolor 'Hogan' & MAST & \\
\hline $29 \mathrm{a}$ & Dichroa versicolor (garden form) & $\mathrm{CN}$ & $8.8 \pm 0.06$ \\
\hline $\mathrm{b}$ & Dichroa versicolor & HW & \\
\hline $\mathrm{c}$ & Dichroa versicolor & HW & \\
\hline $\mathrm{d}$ & Dichroa versicolor & UGA & \\
\hline $\mathrm{e}$ & Dichroa versicolor (labeled D. discolor) & $\mathrm{CN}$ & $8.9 \pm 0.03$ \\
\hline $\mathrm{f}$ & Dichroa versicolor & WG & \\
\hline 30 & Dichroa febrifuga $\times$ Hydrangea macrophylla 'Taube' & $\mathrm{NRC}$ & $12.9 \pm 0.13$ \\
\hline $31 \mathrm{a}$ & Possible intergeneric hybrid, 'Round Blue' & WG & \\
\hline $\mathrm{b}$ & Possible intergeneric hybrid, 'Round Blue' & GN & $6.0 \pm 0.10$ \\
\hline $32 \mathrm{a}$ & Possible intergeneric hybrid, 'White Lace' & WG & \\
\hline $\mathrm{b}$ & Possible intergeneric hybrid, 'White Lace' & GN & $5.9 \pm 0.07$ \\
\hline $33 \mathrm{a}$ & Possible intergeneric hybrid, 'Pink Candy' & WG & \\
\hline b & Possible intergeneric hybrid, 'Pink Candy' & GN & \\
\hline 34 & Hydrangea macrophylla 'Taube' & $\mathrm{NRC}$ & $7.5 \pm 0.05$ \\
\hline 35 & Hydrangea macrophylla 'Ami Pasquir' & AHN & \\
\hline 36 & Hydrangea macrophylla 'Veitchii', & $\mathrm{NRC}$ & $4.7 \pm 0.05$ \\
\hline 37 & Hydrangea macrophylla 'Beni Gaku' & AHN & \\
\hline
\end{tabular}

${ }^{\mathrm{z}} \mathrm{AHN}=$ Amethyst Hill Nursery, Aurora, OR; CF $=$ Crûg Farm Plants, Caernarfon, Wales; $\mathrm{CN}=$ Cistus Nursery, Sauvie Island, OR; GN = Green Nurseries, Fairhope, AL; HW = Heronswood Nursery, Warminster, PA; ITS = Itsaul Plants, Alpharetta, GA; MAST = Stephen F. Austin MAST Arboretum, Nacogdoches, TX; NRC = Tennessee State Nursery Research Center, McMinnville, TN; UGA = University of Georgia, Athens, GA; WG = Woodleigh Gardens, New Plymouth, New Zealand.

${ }^{y}$ Total nuclear DNA content as determined by flow cytometric measurements of 4',6-diamidino-2phenylidole-stained nuclei; $\mathrm{n}=3$.

growing in an area containing various $H$. macrophylla cultivars and D. febrifuga genotypes, whereas sample \#26 was found near a H. indochinesis plant (Glyn Church, personal communication). Four H. macrophylla cultivars, including the parents of the intergeneric hybrids produced from controlled pollinations, were analyzed. Six wild-collected $H$. indochinensis taxa were tested, including one from China (\#25), two from Vietnam with purple abaxial leaf color (\#21 and 23), and three additional plants from Vietnam (\#20, 22, and 24). Seven $D$. versicolor plants were containing $0.4 \mathrm{~mL}$ extraction buffer (Partec CyStain ultraviolet precise P Nuclei Extraction Buffer; Partec GMBH, Münster, Germany). The resulting extract was passed through a $30-\mu \mathrm{L}$ filter into a $3.5-\mathrm{mL}$ plastic tube, to which was added $1.6 \mathrm{~mL}$ Partec CyStain ultraviolet precise P Staining Buffer containing the fluorochrome 4 ', 6-diamidino2-phenylidole. The relative fluorescence of the total DNA was measured for each nucleus using a Partec CyFlow ploidy analyzer (Partec GMBH). For each sample, at least 5000 nuclei were analyzed. Genome sizes were calculated as nuclear DNA content for unreduced tissue (2C) as: 2C DNA content of tissue $=($ mean fluorescence value of sample $\div$ mean fluorescence value of standard) $\times 2 \mathrm{C}$ DNA content of standard. Pisum sativum L. 'Ctirad', with a 2C content of 9.09 pg (Doležel and Bartoš, 2005), was used as the internal standard for all samples except the $D$. versicolor selections, which produced a peak that overlapped with that of pea. For these samples, D. febrifuga GUIZ48 was used as the internal standard and genome size of $D$. versicolor was extrapolated using the genome size estimate for this hexaploid selection.

Simple sequence repeat processing. SSR marker analysis was applied to all 51 plants listed in Table 1; samples that produced identical genotypes are denoted by letters below a single numbered genotype and were not included in further analysis. DNA was extracted from 1- $\mathrm{cm}^{2}$ pieces of fresh leaf tissue using the Qiagen Plant Mini Kit (Qiagen, Valencia, CA), quantified using a NanoDrop Spectrophotometer (Nanodrop Technologies, Wilmington, $\mathrm{DE}$ ), and diluted to a final concentration of $5 \mathrm{ng} / \mu \mathrm{L}$. Amplification was performed using a three-primer protocol described in Rinehart et al. (2006). Except for one SSR locus, the primers shown in Table 2 have been previously described and all sequences were submitted to the National Center for Biotechnology Information GenBank (Reed and Rinehart, 2007; Rinehart et al., 2006). Fluorescence-labeled polymerase chain reaction fragments were visualized by automated capillary gel electrophoresis on an ABI3130xl using ROX-500 size standard (Applied Biosystems, Foster City, CA). GeneMapper Version 4.0 was used to recognize and size peaks (Applied Biosystems). All data were converted to diploid, which resulted in a reduced number of alleles for samples with predicted higher ploidy according to flow cytometry analysis. This arbitrary reduction slightly reduces the observed genetic variation, thereby underestimating genetic diversity among taxa, but the alternative was to code all samples as hexaploid. We choose to diploidize the date because of our interest in hybrid identification, although it underestimates the genetic diversity among higher ploidy $D$. febrifuga genotypes.

Simple sequence repeat data analysis. Data from 31 SSR loci were compiled for the 37 genotypes and analyzed for shared allele frequencies. Nei's minimum genetic distance was calculated for all samples (Nei, 1972). Gene diversity estimates were produced using Nei's 1987 estimator for heterozygosity and 


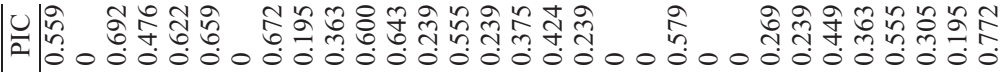
어 II $\stackrel{1}{0} 0$ o

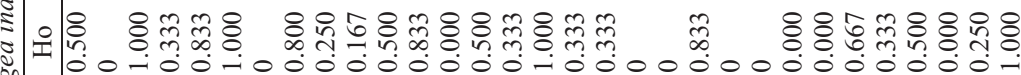
ב⿱艹

$\stackrel{\varrho}{=}$

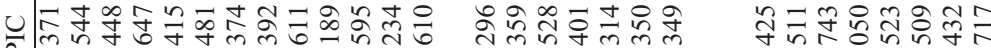
Е

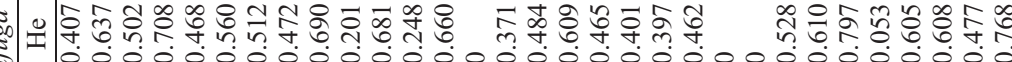
$\frac{3}{\frac{0}{0}}$

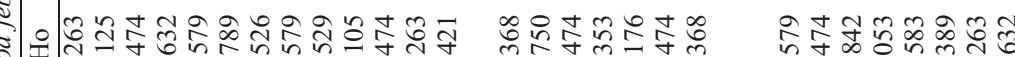
I (2)

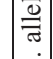

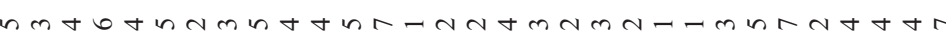
$\dot{z}$

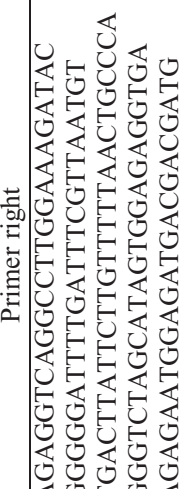

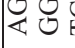$$
\text { प्र }
$$<smiles>C1=[Ge]=C2CCCCC1C2</smiles>
(1)<smiles>[C+]1=CCCC1</smiles><smiles>[C-]1CCCCC1</smiles><smiles>[C]1C=CC1</smiles>

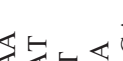<smiles>[CH]1CCC1</smiles>
晒
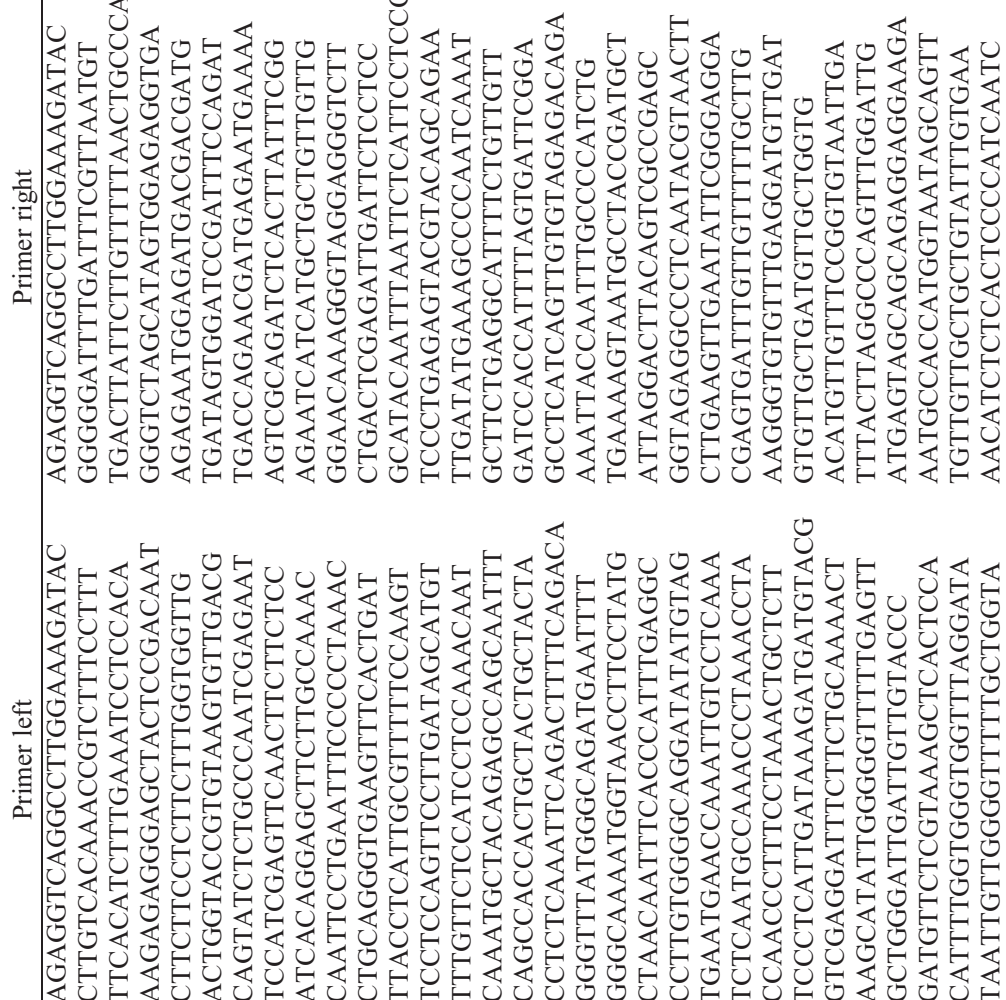

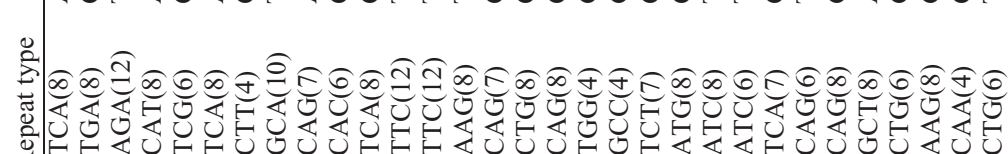

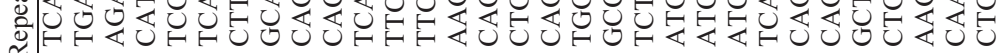

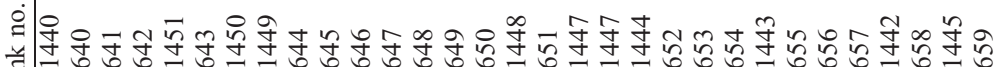

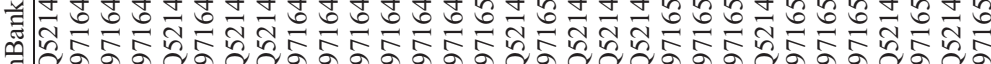

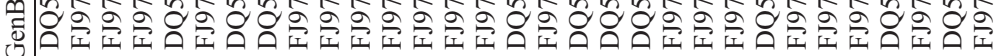

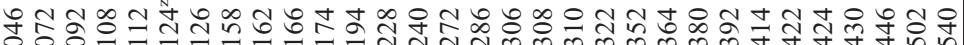

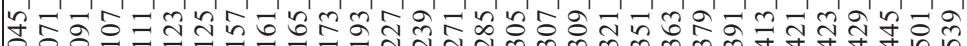
صे

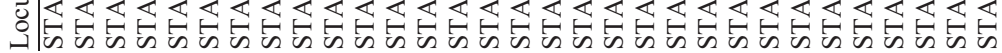

expected gene diversity was determined using FSTATS software (Goudet, 1995; Saitou and Nei, 1987). POPULATIONS Version 1.2.28 was used for phenetic analyses (Langella, 2002). Principal coordinate analysis (PCoA) plots and tree dendrograms were based on Nei's minimum genetic distance matrix and plots were generated using NTSys software (Rohlf, 1992). Neighbor-joining with 1000 bootstrap replicates for statistical support was used to generate a tree phenogram, which was visualized with TreeView (Page, 1996).

\section{Results}

Flow cytometry. Variation in genome size was observed among $D$. febrifuga genotypes (Table 1). A dwarf form and 'Yamaguchi Select' have genome sizes ranging from 17.4 to $17.6 \mathrm{pg}$ DNA, similar to that observed for the GUIZ48 selection, which had previously been identified as being a hexaploid with 108 somatic chromosomes (Reed et al., 2008). Dichroa febrifuga BSWJ6610 (originally listed as D. versicolor), 'Yamaguchi Hardy', and two plants received from a commercial source (identified only as Woodleigh Gardens \#7 and 11) have genome sizes ranging from 12.5 to 12.9 pg DNA. These four genotypes are presumed to be tetraploids. Six $D$. febrifuga genotypes, with genomes ranging from 6.0 to $6.9 \mathrm{pg}$ DNA, appear to be diploids. The diploid genotypes identified in this study are D. febrifuga aff. hirsuta, Chadwell collection, 'Yellow Wings', and three seedlings (samples \#1, 2, and 3) collected in Vietnam.

Genome size estimates for diploid ('Veitchii') and triploid ('Taube') H. macrophylla plants are similar to those reported previously (Jones et al., 2007). The three $H$. indochinesis samples tested had genomes of 4.8 to 5.0 pg DNA, suggesting that these plants are diploids. A range of genome sizes was observed among confirmed and putative intergeneric hybrids. Genome size estimates for two intergeneric hybrids (samples \#27 and 30) produced from controlled crosses are in agreement with previously reported estimates (Reed et al., 2008) as well as with what would be expected from crosses of diploid and triploid $H$. macrophylla with the hexaploid D. febrifuga selection GUIZ48. 'Round Blue' and 'White Lace', which are self-sown seedlings that appeared in a garden in which $D$. febrifuga and H. macrophylla were growing, have genome sizes of 5.9 to $6.0 \mathrm{pg}$, respectively, suggesting that both parental species are diploids. The genome size of the sole $D$. versicolor genotype tested is $8.9 \mathrm{pg}$; this measurement, along with molecular data presented subsequently, indicate that $D$. versicolor is a triploid hybrid between a diploid Hydrangea and a tetraploid D. febrifuga genotype (Table 1, \#29a and 29e).

Simple sequence repeat markers. A subset of SSR markers developed for H. macrophylla (Reed and Rinehart, 2007) effectively document diversity within Dichroa and between related species and cultivars. All 31 markers are based on trinucleotide microsatellite repeats and allele size variation is generally 
consistent with microsatellite evolution (data not shown). Average number of alleles per locus is 3.68 within the $19 \mathrm{D}$. febrifuga genotypes. Mean expected heterozygosity is 0.464 and mean polymorphic information content (PIC) is 0.401 . Three loci are fixed within D. febrifuga (Table 2). The average number of alleles per locus in the six $H$. indochinensis genotypes is lower at 2.84 . Mean expected heterozygosity among these samples is 0.451 and mean PIC is 0.364 . Six loci are fixed within $H$. indochinensis, which is consistent with the lower heterozygosity. We are not able to estimate genetic diversity within $D$. versicolor because six of the seven samples appear to be clones of the same plant, leaving us with only two unique genotypes for this species (Table 1). Diversity within wild-collected $D$. febrifuga and $H$. indochinensis is comparable to published diversity among other wild-collected hydrangea species (Reed and Rinehart, 2007).

Cluster analysis by neighbor-joining produces a dendrogram supported by bootstrap replicates. Dichroa febrifuga samples split into two main groups. One consists of most of the named cultivars (Fig. 1, samples \#14-19). The other cluster divides into two subgroups, but this bifurcation has less than $50 \%$ bootstrap support. The three $D$. febrifuga groups correlate with genome size variation measures (Table 1). Hexaploid, tetraploid, and diploid taxa cluster together except for sample $\# 10$, which is a tetraploid plant that clusters with diploid genotypes. Hydrangea indochinensis samples cluster regardless of geographic origin, although the sample from China has a longer branch length and is sister to other accessions (Fig. 1, \#25). Dichroa versicolor samples (Fig. 1, \#28 and 29) cluster separate from $D$. febrifuga but cannot be differentiated from intergeneric hybrids included in this study (Fig. 1, \#27 and 30-33).

Genetic similarity between $D$. versicolor and intergeneric hybrids is visualized in a PCoA plot (Fig. 2). The three species ( $D$. febrifuga, $H$. macrophylla, and $H$. indochinesis) group as individual clusters. The two

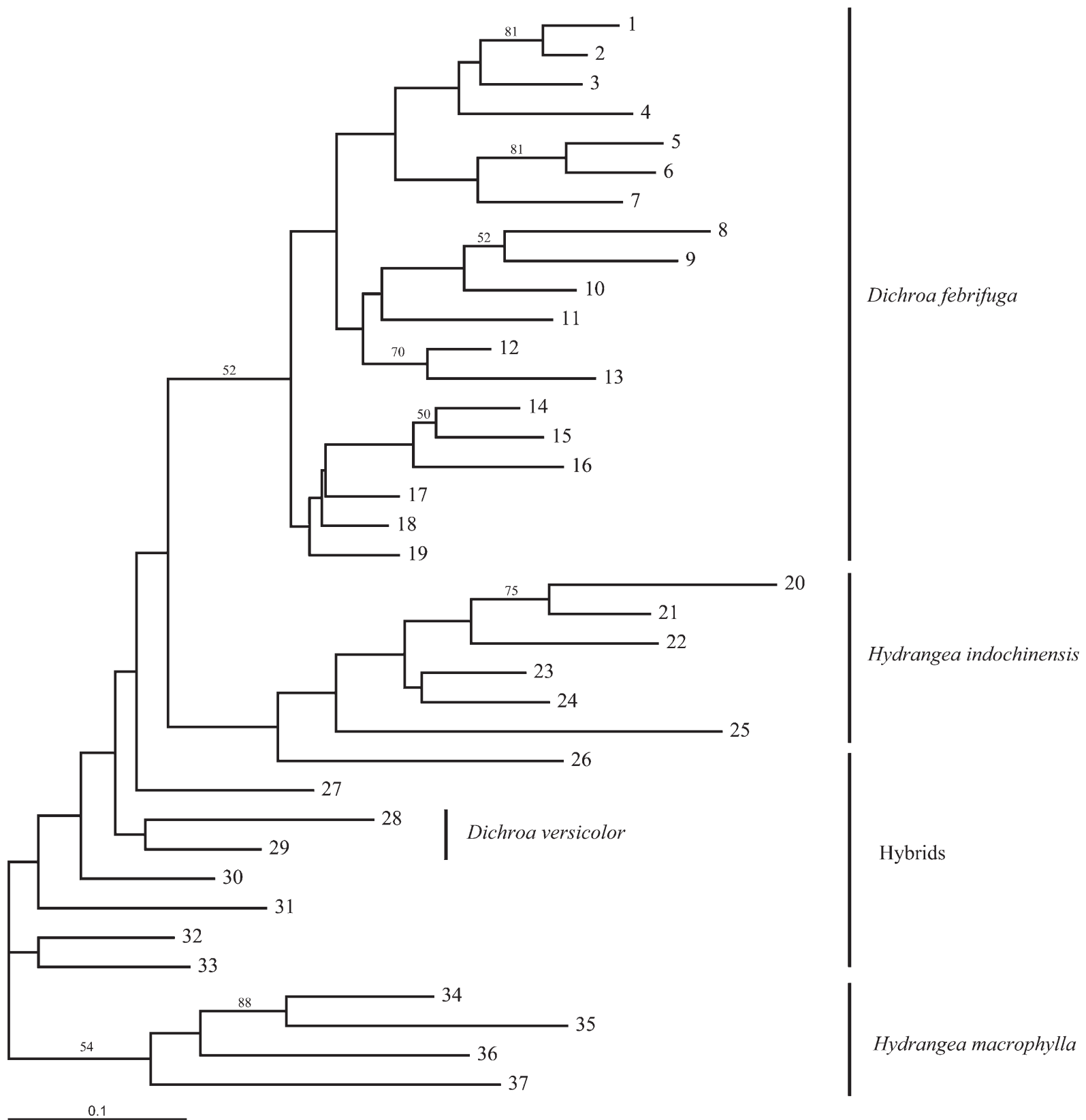

Fig. 1. Neighbor-joining tree dendrogram of 37 genotypes using 31 simple sequence repeat markers. Bootstrap values from 1000 replicates are shown above branches where greater than $50 \%$. Tree is rooted with $H$. macrophylla cultivars. Dichroa febrifuga samples cluster in two groups with most named cultivars $(\# 14,18)$ and ornamental selections $(\# 15,16,17)$ in one group and wild-collected germplasm clustering in the other. H. indochinensis samples (\#20-24) cluster separate from other taxa but $D$. versicolor $(\# 28,29)$ appear mixed with intergeneric hybrids $(\# 27,30-33)$. Long branch lengths for $D$. febrifuga and H. indochinensis are expected for wild-collected samples. 


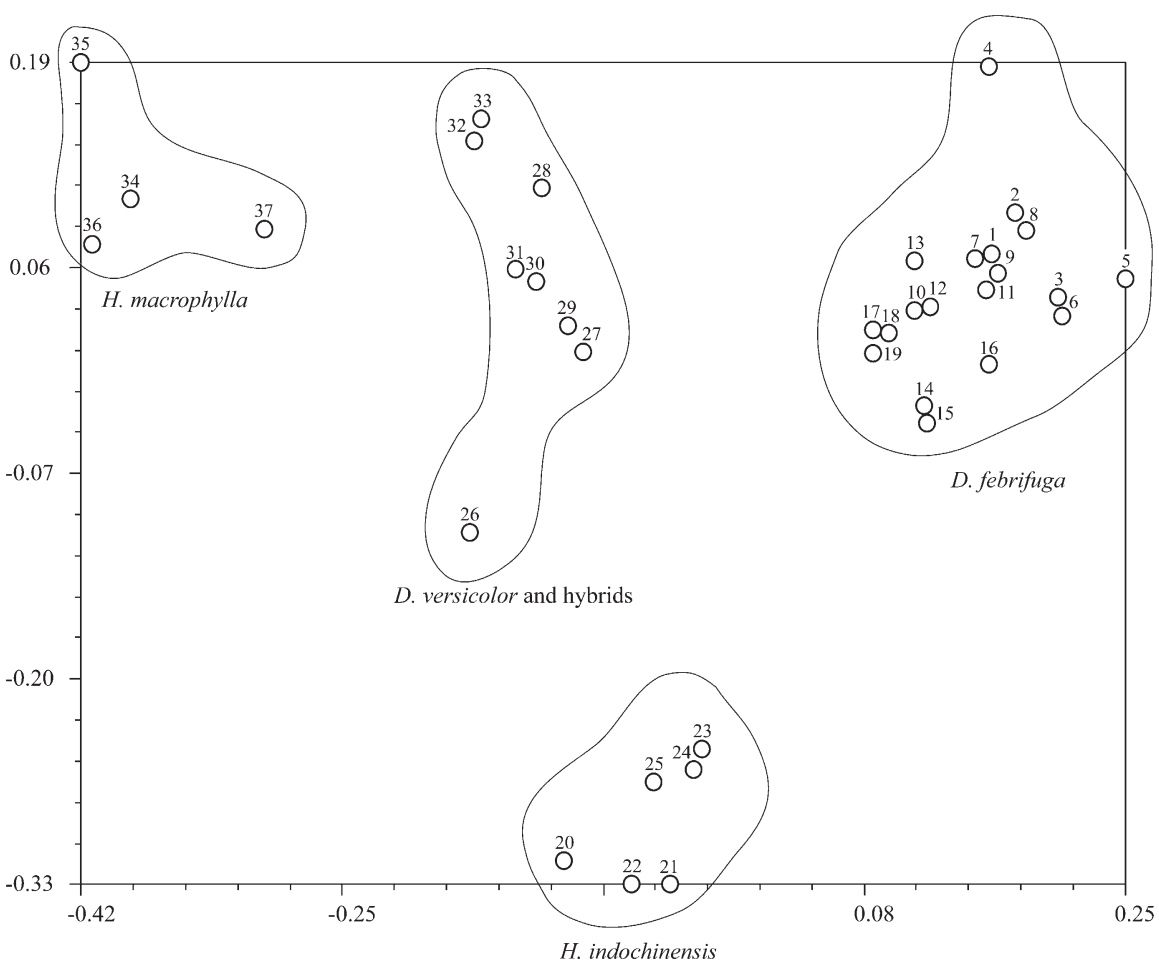

Fig. 2. Principal coordinates analysis plot of the 37 genotypes using Nei's minimum genetic distance (Nei, 1972). The $X$ and $Y$ axis represent $38.45 \%$ and $23.29 \%$ of the genetic diversity, respectively. Samples cluster by species and groups circled and labeled. Hybrids, including intergeneric hybrids between $D$. febifuga and H. macrophylla (\#27 and \#30-33) and the interspecific hybrid between $H$. indochinensis and H. macrophylla (\#26), are intermediate between parent species. Included in this group are two $D$. versicolor genotypes $(\# 28,29)$.

confirmed intergeneric hybrids (\#27 and 30) cluster with D. versicolor (\#28 and 29), 'Round Blue' (\#31), 'White Lace' (\#32), and 'Pink Candy' (\#33). Sample \#26, which is confirmed by SSR as an interspecific hybrid, lies intermediate between parent species $H$. indochinensis and H. macrophylla.

\section{Discussion}

Ploidy variation is observed in D. febrifuga and also among hybrids of $D$. febrifuga and $H$. macrophylla. Previously described $\mathrm{F}_{1}$ intergeneric hybrids displayed relatively uniform phenotypes, as expected for first-generation allopolyploids, but lacked robust expression of H. macrophylla traits (Kardos, 2008; Reed et al., 2008). Although significant phenotypic variation is theoretically expected among $\mathrm{BC}_{1}$ or $\mathrm{F}_{2}$ progeny, $H$. macrophylla traits may still be underrepresented because of the hexaploid D. febrifuga background (Josh Kardos, personal communication). Conversely, preliminary observations of 'Round Blue'and 'White Lace', in which both parents are diploid, suggest an increase in hydrangea trait expression in the $\mathrm{F}_{1}$ generation, including the presence of showy flowers with enlarged sepals, which was not seen in other intergeneric hybrids until backcrossed to H. macrophylla (Reed et al., 2008). Given the fertility among documented hybrids, our identification of diploid, tetraploid, and hexaploid $D$. febrifuga increases the potential for expanding hydrangea breeding by wide hybridization, especially because diploid and triploid H. macrophylla cultivars have also been characterized (Cerbah et al., 2001; Jones et al., 2007; Zonneveld, 2004).

Using SSR data, we cannot determine if the tetraploid and hexaploid D. febrifuga are the result of autopolyploidy. It is reasonable that $D$. febrifuga tetraploids might be the result of diploids crossing with hexaploids to create allopolyploids. Cytological studies are needed and could be compared with the physical map for $H$. macrophylla given the close genetic relationship (Van Laere et al., 2008). Synthetic D. febrifuga tetraploids could also be created by antimitotic chemical treatments for comparative purposes.

Phenotypic diversity within $D$. febrifuga was not measured because many of the plants are only represented by tissue samples. Blue fruits are ubiquitous in all D. febrifuga tested but may vary in size, coloration, and duration on the plant during winter months, particularly among ploidy levels. Preliminary observations of the living $D$. febrifuga plants listed in Table 1 suggest that growth habit varies considerably among taxa with upright and compact shapes being desirable. Further collection and testing of $D$. febrifuga germplasm is warranted not just to evaluate ornamental traits to incorporate into hydrangea breeding, but also to possibly revise the taxonomy for $D$. febrifuga, which based on the accumulated data, including this study, indicate that it should be designated a Hydrangea species.

Dichroa taxonomy is complicated by our finding that two unique $D$. versicolor genotypes cluster with confirmed intergeneric hybrids between $D$. febrifuga and $H$. macrophylla (Fig. 2). The native ranges for H. macrophylla and D. febrifuga do not share extensive overlap except in the Eastern Himalayas (Hinkley, 2005; McClintock, 1957); however, H. indochinensis is found in the Himalayas, including Nepal, China, and India as well as Thailand and down through Vietnam (McClintock, 1957) and D. febrifuga is found in Nepal, southern China, and Southeast Asia (Hinkley, 2005). Despite overlap in geographic ranges, SSR data do not support a relationship between $H$. indochinensis and D. versicolor, indicating instead that the more likely parents of $D$. versicolor are $H$. macrophylla and $D$. febrifuga. These latter two species freely interbreed, as documented here with three self-sown, open-pollinated hybrids. We only found references to a single wild-collected $D$. versicolor plant from Northern Bhurma, which may account for the predominance of a single genotype in our samples (Church, 2001). Future collecting could look for $D$. febrifuga and H. macrophylla in this immediate area.

Although H. macrophylla has been cultivated for over 300 years, the germplasm base used for improving this species has been limited. Wide hybridization offers potential for incorporating unique new traits into this popular ornamental species. This study demonstrates the range of genetic and ploidy diversity available within $D$. febrifuga available for use in H. macrophylla genetic improvement efforts. In addition, $H$. indochinesis is identified as another species that freely hybridizes with $H$. macrophylla and could serve as a source of ornamental traits such as purple foliage. Prior research indicates that D. febrifuga should be renamed a Hydrangea species (Hufford, 2001; Hufford et al., 2001; Rinehart et al., 2006; Soltis et al., 1995). This study further demonstrates the need for a taxonomic revision of Dichroa by suggesting that $D$. versicolor may be a naturally occurring hybrid species.

\section{Literature Cited}

Bean, W.J. 1970. Trees and shrubs hardy in the British Isles. Murray, London, UK.

Cerbah, M., E. Mortreau, S. Brown, S. SiljakYakovlev, H. Bertrand, and C. Lambert. 2001. Genome size variation and species relationships in the genus Hydrangea. Theor. Appl. Genet. 103:45-51.

Chittendon, F. 1956. RHS dictionary of plants plus supplement. Oxford University Press, Oxford, UK.

Church, G. 2001. Hydrangeas. Firefly Books, Cassell, London, UK.

Doležel, J. and J. Bartoš. 2005. Plant DNA flow cytometry and estimation of nuclear genome size. Ann. Bot. (Lond.) 95:99-110.

Duke, J.A. and E.S. Ayensu. 1985. Medicinal plants of China. Reference Publications, Inc., Algonac, MI.

Goudet, J. 1995. FSTAT (Version 1.2): A computer program to calculate F-statistics. J. Hered. 86: 485-486.

Hinkley, D.J. 2003. A plantman's observation on the genus Hydrangea. Davidsonia 14:31-58. 
Hinkley, D.J. 2005. Plants of merit. Dichroa febrifuga. Horticulture 102:79.

Hufford, L. 2001. Ontogeny and morphology of the fertile flowers of Hydrangea and allied genera of tribe Hydrangeeae (Hydrangeaceae). Bot. J. Linn. Soc. 137:139-187.

Hufford, L., M.L. Moody, and D.E. Soltis. 2001. A phylogenetic analysis of Hydrangeaceae based on sequences of the plastid gene matK and their combination with rbcL and morphological data. Int. J. Plant Sci. 162:835-846.

Jones, K.D., S.M. Reed, and T.A. Rinehart. 2006. Wide crosses in the Hydrangeaceae: Dichroa febrifuga $\times$ Hydrangea macrophylla. Proc. Southern Nursery Assn. Res. Conf. 51:577579.

Jones, K.D., S.M. Reed, and T.A. Rinehart. 2007. Analysis of ploidy level and its effects on guard cell length, pollen diameter, and fertility in Hydrangea macrophylla. HortScience 42:483488.

Kardos, J.H. 2008. Interspecific and intergeneric hybridization involving Hydrangea macrophylla (Thunberg) Seringe and inheritance studies in H. macrophylla. $\mathrm{PhD}$ diss., Univ. of GA, Athens, GA.

Kardos, J.H., C.D. Robacker, M.A. Dirr, and T.A. Rinehart. 2006. Production and verification of hybrids from Hydrangea macrophylla $\times H$. angustipetala and $H$. macrophylla $\times$ Dichroa febrifuga. Proc. Southern Nursery Assn. Res. Conf. 51:570-572.

Langella, O. 2002. POPULATIONS, A free population genetics software. 26 June 2009. <http:// bioinformatics.org/ $\sim$ tryphon/populations/>

McClintock, E. 1957. A monograph of the genus Hydrangea. Proc. Calif. Acad. Sci. 29:147-256.

Nei, M. 1972. Genetic distance between populations. Am. Nat. 106:283-292.

Page, R.D. 1996. TreeView: An application to display phylogenetic trees on personal computers. Comput. Appl. Biosci. 12:357-358.

Phillips, R. and M. Rix. 1998. Conservatory and indoor plants. Pan Books, London, UK.

Reed, S.M., K.D. Jones, and T.A. Rinehart. 2008. Production and characterization of intergeneric hybrids between Dichroa febrifuga and $\mathrm{Hy}$ drangea macrophylla. J. Amer. Soc. Hort. Sci. 133:84-91.

Reed, S.M. and T.A. Rinehart. 2007. Simple sequence repeat marker analysis of genetic relationships within Hydrangea macrophylla. J. Amer. Soc. Hort. Sci. 132:341-351.

Rinehart, T.A. and S.M. Reed. 2008. Relationships between Hydrangea indochinensis, H. macrophylla, H. scandens, and Dichroa febrifuga based on SSR markers. Proc. Southern Nursery Assn. Res. Conf. 53:195-197.

Rinehart, T.A., B.E. Scheffler, and S.M. Reed. 2006. Genetic diversity estimates for the genus
Hydrangea and development of a molecular key based on SSR. J. Amer. Soc. Hort. Sci. 131:787-797.

Rohlf, F.J. 1992. NTSYS: Pc numerical taxonomy and multivariate analysis system. Version 1.70 Exeter Publ., Setauket, NY.

Saitou, N. and M. Nei. 1987. The neighbor-joining method: A new method for reconstructing phylogenetic trees. Mol. Biol. Evol. 4:406425.

Shumei, H. and B. Bartholomew. 2001. Dichroa, p. 404 406. In: Pan, J., C. Gu, S. Huang, C. Wei, S. Jin, L. Lu, S. Akiyama, C. Alexander, B Bartholomew, J. Cullen, R. Gornall, U. Hultgard, H. Ohba, and D. Soltis (eds.). Flora of China. Vol. 8. 26 June 2009. <http://flora.huh harvard.edu/china/PDF/PDF08/DICHROA.pdf>.

Soltis, D.E., Q.-Y. Xiang, and L. Hufford. 1995. Relationships and evolution of Hydrangeaceae based on rbcL sequence data. Amer. J. Bot. 82:504-514.

Van Laere, K., J. Van Huylenbroeck, and E. Van Bockstaele. 2008. Karyotype analysis and physical mapping of 45S rRNA in Hydrangea species by fluorescence in situ hybridization. Plant Breed. 127:301-307.

Zonneveld, B.J.M. 2004. Genome size in Hydrangea, p. 245-251. In: Van Gelderen, C.J. and D.M. van Gelderen (eds.). Encyclopedia of hydrangeas. Timber Press, Portland, OR. 